\title{
Cerebral astrocytoma in association with HIV infection
}

\author{
J GASNAULT, ${ }^{*}$ F X ROUX, ${ }^{*}$ C VEDRENNE $\dagger$ \\ From the Departments of Neurosurgery* and Neuropathology, $\dagger$ Hôpital Sainte-Anne, Paris, France
}

SUMMARY Cerebral astrocytoma has been found in two patients with AIDS related conditions. The fortuity of this unusual association is discussed, insofar as immunosuppression could favour the growth of certain neoplasms.

The central nervous system (CNS) tumours that occur in acquired immune deficiency syndrome (AIDS), are usually primary cerebral lymphomas, or CNS involvement secondary to systemic lymphomas. ${ }^{12} \mathrm{We}$ have found only four cases of brain metastasis from Kaposi's sarcoma,${ }^{34}$ including one with meningeal and intracerebral localisation. One report refers to the association of cerebral glioma and human immunodeficiency virus (HIV) infection but without description of the case. ${ }^{5}$ Among 33 patients with neurological diseases, including 20 intracerebral space-occupying lesions, associated with different forms of HIV infection (AIDS, AIDS-related-complex (ARC), HIV seropositive healthy carrier), we report two cases with an intracerebral astrocytoma.

Case 1 A 43 year old homosexual male, with HIV serum antibodies, was admitted in November 1985 with generalised seizures. His general condition had been deteriorating during the past month, and he had complained of headache for 3 months. He did not have lymphadenopathy or signs of opportunistic infection, but the tuberculin skin-test was negative. Blood count showed lymphopenia with $\mathrm{T} 4 / \mathrm{T} 8$ ratio of 0.5 . The patient had right pyramidal signs and a right lower homonymous quadranopsia. The fundus was normal. A CT scan showed a large space-occupying lesion (fig 1), posteriorly and deeply seated in the left hemisphere, with a heterogeneous ring-enhancement after contrast infusion. The lesion caused compression and dilatation of the ventricular system. In spite of antitoxoplasmosis and anti-oedema treatment, features of increasing intracranial pressure led to

Address for reprint requests: Professor F X Roux, Centre Hospitalier Sainte-Anne, 1 Rue Cabanis, 75674 Paris Cedex, France

Received 31 March 1987 and in revised form 10 July 1987. Accepted 24 August 1987 the institution of external ventricular drainage. A brain biopsy showed a pilocytic astrocytoma of intermediary grading (fig 2). Two days later bilateral intracerebral haematoma developed, probably related to a thrombocytopenia induced by pyrimethamine. The patient's consciousness deteriorated quickly and he died 10 days later.

Case 2 A 19 year old male heroin addict with circulating HIV antibodies, was admitted in May 1985 for investigation

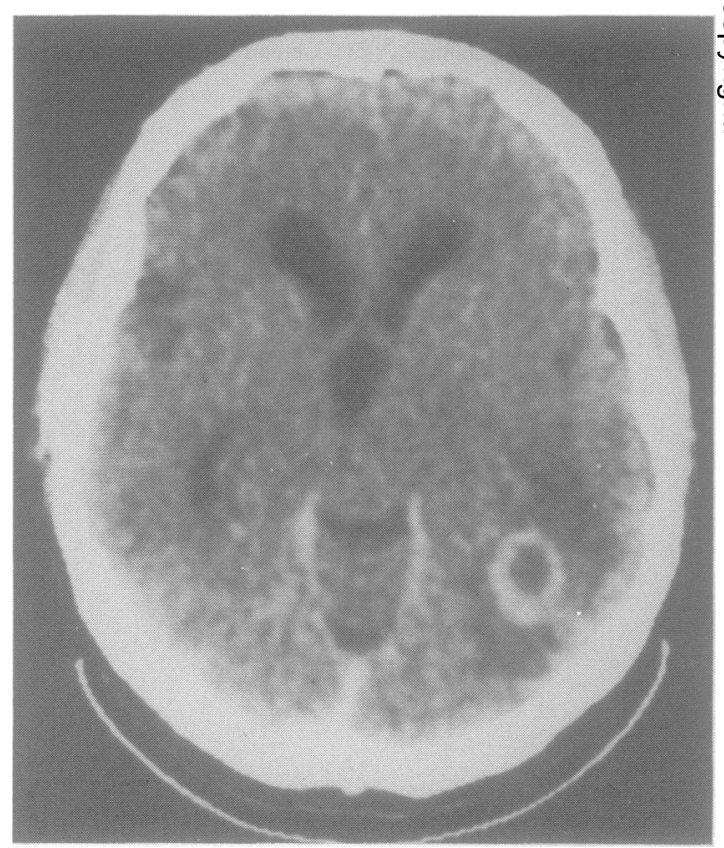

Fig 1 Patient 1, cranial CT scan: left posterior spaceoccupying lesion, with ring-enhancement. 


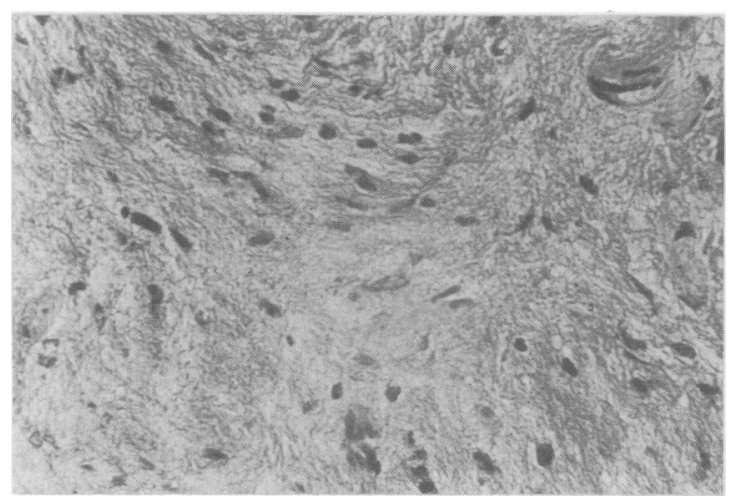

Fig 2 Patient 1, cerebral biopsy. Hemateine-PhloxineSafran, $\times 250$. Pilocytic astrocytoma of adult type.

of a partial, left sensory-motor seizure with secondary generalisation, followed by a transient paresis in the same area. The first cranial CT scan was normal. A lumbar puncture revealed a protein level of $0.72 \mathrm{~g} / \mathrm{l}$ and white blood cells count of $5 \mathrm{~mm}^{3}$. Previous medical history included an active chronic hepatitis and persistent generalised lymphadenopathy. The patient had tuberculin skin test anergy and a normal white blood cell count. The appearance of a moderate, but progressive left hemiparesis led to further investigations in August 1985. The second CT scan revealed a space-occupying lesion in the right central sulcus area, with homogeneous contrast-enhancement (fig 3). Antitoxoplasmosis treatment was tried without benefit. A brain biopsy in

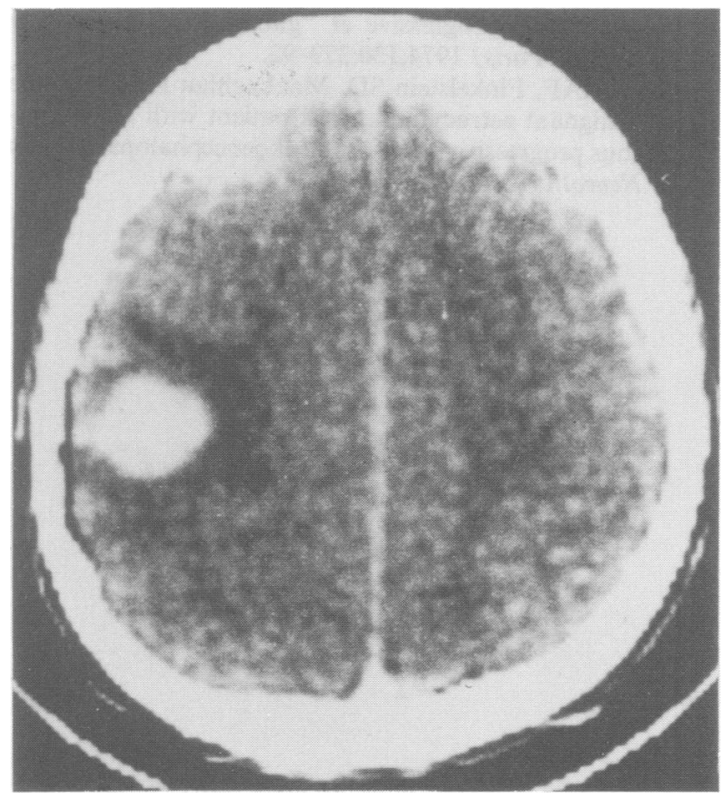

Fig 3 Patient 2, cranial CT scan: right central spaceoccupying lesion.

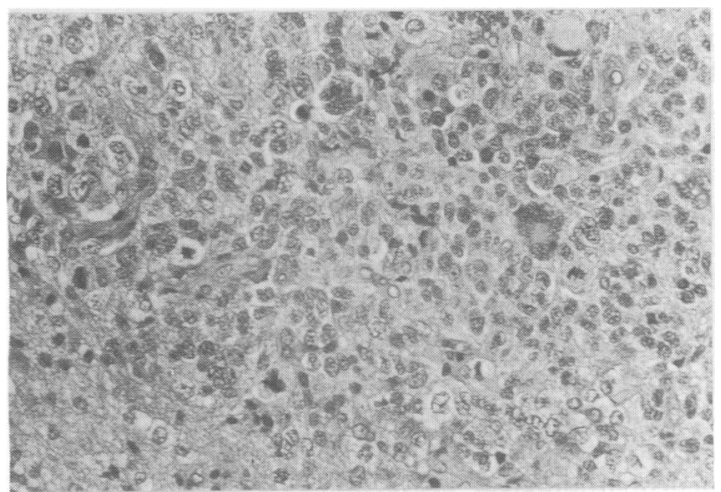

Fig 4 Patient 2: Cerebral biopsy. Hemateine-Phloxine-

Safran, $\times 250$. Malignant astrocytoma grade IV. Astrocytic proliferation with cells in mitosis and many cellular abnormalities.

December 1985 showed a malignant astrocytoma (fig 4). Because of its localisation in a functional area the tumour could be treated only with radiotherapy. After a short-lived improvement, there was a neurological recurrence, and the patient died of raised intracranial pressure in August 1986.

\section{Discussion}

Previously unrecognised neurological complications have occurred in patients with HIV infection in the absence of full-blown AIDS, especially the AIDSdementia-complex. ${ }^{6}$ The unusual discovery of astrocytoma in two patients with positive serum HIV antibodies and AIDS-related complex (one with immunological abnormalities of AIDS and the other with persistent generalised lymphadenopathy) raises the possibility that the association is fortuitous on account of the common event of cerebral astrocytoma.

HIV belongs to the group of the lentiviruses, which, unlike oncoviruses, are not transforming agents, but are characterised by a cytopathogenic effect, killing the infected cells. ${ }^{7}$ HIV, which is a well-established neurotropic virus, ${ }^{8}$ is probably not directly implicated in the genesis of a malignant glial proliferation. HIV had been detected in macrophages and multinucleated giant cells in brain tissue from AIDS patients, ${ }^{910}$ but rarely in glial cells. ${ }^{8}$ Yet, as HIV destroys immune defences, it could favour the induction of some neoplasms by oncoviruses." Such a mechanism is considered possible in the pathogenesis of B-lymphoma (Epstein-Barr virus) and Kaposi's sarcoma (cytomegalovirus), related to AIDS. ${ }^{17}$ The activation of some oncogenes has been observed in CNS tumours. ${ }^{12}$ Some authors have suggested that the Simian virus 40 (SV 40), one of the agents of progressive multifocal leukoencephalopathy, may be involved in the induction of such tumours. ${ }^{13}$ The SV 40 , like 
other papovaviruses, is an oncogenic virus capable of inducing brain tumours in animals and causing mutation of human cells in vitro. ${ }^{14}$ Evidence of SV 40 has been found in human brain tumours. ${ }^{14}$ The observation of progressive multifocal leukoencephalopathy in association with multiple gliomas ${ }^{1516}$ is of special interest insofar as progressive multifocal leukoencephalopathy occurs almost always in patients with immune deficiency.

Our two cases extend the list of possible causes of an intracranial space-occupying lesion in a patient with AIDS or a related syndrome. Toxoplasmosis ${ }^{2}$ remains the most common cause, and was found in 17 of our 22 neuropathological cases. However, neurotoxoplasmosis is not the only cerebral disease in these patients that might benefit from specific treatment. Whenever the diagnosis of toxoplasmosis is not confirmed by the results of a therapeutic trial, brain biopsy should be performed.

\section{References}

1 Ioachim HL, Cooper MC, Hellman GC. Lymphomas in men at high risk for acquired immune deficiency syndrome (AIDS). Cancer 1985;56:2831-42.

2 Levy RM, Bredesen DE, Rosenblum ML. Neurological manifestations of acquired immunodeficiency syndrome (AIDS): Experience at UCSF and review of the literature. J Neurosurg 1985;62:475-95.

3 Hymes KB, Cheung T, Greene JB, et al. Kaposi's sarcoma in homosexual men-a report of eight cases. Lancet 1981;ii:598-600.

4 Gorin FA, Bale JF, Halks-Miller M, Schwartz RA. Kaposi's sarcoma metastatic to the CNS. Arch Neurol 1985;42:162-5.

5 Ho DD, Rota TR, Schooley RT, et al. Isolation of HTLV-III from the cerebrospinal fluid and neural tissues of patients with neurologic syndromes related to the acquired immunodeficiency syndrome. $N$ Engl $J$ Med 1985;312:1-4.

6 Navia BA, Price RW. The acquired immunodeficiency syndrome dementia complex as presenting or sole manifestation of human immunodeficiency virus infection. Arch Neurol 1987;44:65-9.

7 Haase AT. Pathogenesis of lentivirus infections. Nature 1986;322:130-6.

8 Wiley CA, Schrier RD, Nelson JA, Lampert PW, Oldstone MB. Cellular localization of human immunodeficiency virus infection within the brain of acquired immune deficiency syndrome patients. Proc Natl Acad Sci USA 1986;83:7089-93.

9 Sharer LR, Epstein LG, Cho E-S, et al. Pathologic features of AIDS encephalopathy in children: Evidence for LAV/HTLV-III infection of brain. Hum Pathol 1986;17:271-84.

10 Koenig S, Gendelman HE, Orenstein JM, et al. Detection of AIDS virus in macrophages in brain tissue from AIDS patients with encephalopathy. Science 1986;233:1089-93.

11 Sonnabend J, Witkin SS, Purtilo DT. Acquired immunodeficiency syndrome, opportunistic infections, and malignancies in male homosexuals: a hypothesis of etiologic factors in pathogenesis. JAMA 1983;249:2370-4.

12 Breakefield XO, Stern DF. Oncogenes in neural tumors. TINS 1986;9:150-5.

13 Geissler E. Etiology of intracranial tumors. Surg Neurol 1985;24:685.

14 Ibelgaufts $\mathrm{H}$, Jones KW. Papovavirus-related RNA sequences in human neurogenic tumours. Acta Neuropathol (Berl) 1982;56:118-22.

15 Castaigne P, Rondot P, Escourolle R, Ribadeau-Dumas JL, Cathala F, Hauw JJ. Leucoencéphalopathie multifocale progressive et "gliomes" multiples. $\operatorname{Rev}$ Neurol (Paris) 1974;130:379-92.

16 Sima AAF, Finkelstein SD, MacLachlan DR. Multiple malignant astrocytomas in a patient with a spontaneous progressive multifocal leukoencephalopathy. Ann Neurol 1983;14:183-8. 